\title{
Editorial
}

\section{A teacher is not just a teacher}

\author{
Satyam Prakash \\ Editor, JMCJMS
}

Teachers are the largest professional group engaged in human development activities. Teaching is a profession - indeed a noble one, conceptually and ideally [1]. It is also different from other professions because of its multitude of dimensions. Malala Yousafzai states that "One book, one pen, one child, and one teacher can change the world". Teaching is considered as one of the most important aspects of the student learning process. The $21^{\text {st }}$ century teaching is however a different perspective, learning could never happen the way it is happening these times. Learning happens everywhere, all the time, on any topic, assisting any learning style. Great students are the result of great teachers [2].

From pre-school to medical school, we get teachers who teach us in different forms and we gain knowledge from them. A general question arises, whom we can mention as true/great teachers? Those who only teaches or anyone else! Prof. P. Ravi Shankar, a pharmacologist and medical educator proclaims in his article "The best teacher is the one who does not teach!" [3]. I argued within myself, can a teacher be a best teacher or a good teacher without teaching? May be or may not be, but when we discuss good teacher/best teacher, we conventionally answer about a dedicated teacher who is committed to and keen to motivate his/her students in whatever way possible. Rather than this traditional remark, a teacher cannot be a true teacher without motivating, inspiring, and creating belief in their ability among students with the modes of teaching to acquire knowledge and skills.

Teaching is a means of offering a unique, definite, and essential social service through specialized training which is in the form of facilitation of learning, based on the beliefs, needs, and practices of each community and each individual [4]. Teaching is a complex craft. Teaching is often referred to as a job, sometimes as a career, or even a profession, but it is far more than that the choice as a way of life, or even a way of being. The teacher's journey represents a lifelong commitment to learning, not only about the content area, grade level, curricular changes, school policy, and technological innovations, but about true passion for new knowledge and skills that proves more effective as a professional and a human being [5,6].

The first principle of true teaching is that nothing can be taught. Rather, it has to be fetched out and developed from within the 
learner; and this is the art of a true teacher. Although, there are different aspects in which we talk about the teachers, but at this point I remember a famous political sociologist of Nepal, Late. Prof. Dr. Ram Kumar Yadav who used to say "Parent is the first teacher and teacher is the second parent. A teacher is not just a teacher." A teacher bears not only the responsibility of students; they are the mirrors of the world. They are the guardians having the responsibility of society as well as the country.

Being a teacher at a medical school, my shoulders have additional responsibility towards conveying and decoding the language of medical science into the minds of learners. No doubt, medical education is one of the most difficult and complex fields in the educational arena. Medical profession is considered as one of the most prestigious and respectful, probably due to the fact that it is directly linked with human lives and patients often have no choice in this regard $[7,8]$. Teaching is a very complex skill and art. Teaching towards medico buds is not a simple task but a tedious job. It requires eagerness, self-discipline, hard-work, practice and feedback to make sure that you are on the right track. Even those endowed with inherent talent, must undergo training to improve their performance.

Teaching in the medical school requires proficient knowledge of motivating the learner; assess competence, and the skill to deal with competing demands of patient care, research and education. The teacher at medical school is not just an instructor or a task master; he/she is a helper and a guide who fits into many different roles; all at the same time. They are the ones who pave the way in the thinking and making of future doctors. The functions of medical teachers extend far beyond the mere imparting of theoretical, stereotype bookish concepts or developing the routine protocol of clinical skills. Their duties include the framing of personal and professional growth among medical students, while developing among them, a sense of responsibility for themselves and the community and instilling within the medical learners, the requisite ethical standards for fulfilling the Hippocratic Oath of physicians [9].

Teaching facilitates learning and encourages the learners to learn in a better way. The purpose of teaching is not merely dispensing information, but to develop skills and attitude also [10]. In recent years, with the use of new teaching and learning methods, the focus of assessment has shifted to the use of higher cognitive abilities, communication skills, IT skills and professionalism. Focus is also shifting from competency based education to outcome based education and workplace performance assessment [5]. Teaching programme comprises of all aspects of teaching and learning, both formative and summative assessment and proposed curricular changes like integrated teaching, early clinical exposure, internal assessment and E-learning $[6,11]$.

Traditionally students were expected to absorb most of their medical education by attending timetabled lectures and wardrounds, moving rapidly from one subject to the next in a crowded curriculum. In recent years the importance of active, self directed learning in higher education has been recognized. Today, the teacher of medical school is expected not only to be well versed in the theoretical concepts of books or appropriate clinical skills; he/she is expected to be a technological multimedia expert as well; who can effectively operate the modern 
pedagogic tools of computer assisted learning, digital imaging and e-learning. How a teacher approaches the task is critical, with a proper understanding of roles, a passion for work, professionalism in the environment and appropriate skills to achieve learning objectives in harmony with the students. An article published in 2000 examines the twelve roles of a medical teacher. These roles are: 'student assessor, curriculum evaluator, curriculum planner, course organizer, study guide producer, resource material creator, clinical or practical teacher, lecturer, teaching role model, on-the-job role model, learning facilitator and mentor' [12].

It has been four decades since the beginning of undergraduate medical education in Nepal and more than three decades of postgraduate medical education. [13,14]. Altogether, 20 medical schools are running as both government and private affiliated with Institute of Medicine (IOM), Kathmandu University (KU) however other two Patan Academy of Health Sciences (PAHS) and BP Koirala Institute of Health Sciences (BPKIHS) are autonomous. From the budding stages of medical institutions, teachers have been involved in teaching $\mathrm{MD}, \mathrm{MSc}$ and $\mathrm{PhD}$ specialization in different subjects in medical science. Teachers at the medical schools have their definite identity and social status in the society.

At the beginning stages, teacher shortages were common in medical schools of Nepal. The teachers are working from Nepal and India and still helping in many ways in the development of Medical Science here. They have contributed tremendously in the development of medical sciences in Nepal. Rules and regulations for medical teachers among different universities within the same country are different. A criterion should be uniform so that teachers can give their best in the medical schools. Most of the Nepalese and some of the Indian faculties are considered as legends in the development of teaching and learning activities in Medical science of Nepal. Although, they have been working at the same place with different degrees to medical students but, there has always been identity and personality clash between the teachers with their degrees, academic qualification, superiority complex and quality teaching all over here.

Teachers may differ radically from each other in qualification, technique of connecting with students, teacher, and subject in a community of learning. But, they should be focused towards passion of effective quality teaching and sound healthy competitive environment at medical schools. Also, degree of control over their work environments, high prestige and differences is significant at job place with non-professionals. Degree and designation both are important but degree or designation should not create any type of controversy at a temple of education in teaching learning aspects. Professionalism should be developed to create hope, joy and healthy environment in teaching for teachers. A number of studies have found a high degree of enthusiasm for teaching in medical schools and many clinicians derive satisfaction from and maintain a strong commitment to teaching [15-18]. There is, however, a perception that teaching does not receive sufficient recognition or prioritization by medical schools, and that teaching quality is compromised by increasing service pressures and the growing student population $[15,16,18]$.

Governments and educational sector stakeholders invest valuable time, effort, and 
resources in their efforts to affect change and improve the education system of Medical Science. Undoubtedly, it should be improved and changed as there is chaotic situation all over here in medical schools. Currently, as per the same act, article and Binium-1 of Nepal Medical Council third amendment2056 B.S., the Ministry of Health, Government of Nepal sanctioned/approved the recommendations forwarded by Nepal Medical Council on Jestha 19, 2074 B.S (2nd June, 2017 AD) towards formulation of Accreditation Standards for the MBBS Program 2017, where the number of teaching faculties in medical schools has been decreased and also the degree bias decision especially in basic sciences [19] is also found to be relevant in Nepal. Also, the decision by the regulating bodies regarding head of departments and Supervisors raised a new debatable issue in Nepal. But, a question arises that decreasing the number of faculties and or degree bias based decision by the regulating bodies will lead to the quality assurance in under-graduate Medical education program in Nepal? Rules and regulations are to be followed, not to be broken. But, if disparities and differences are found it should be amended and rectified.

The rewards of teaching are sometimes immediate and many times long-term. In spite of all the benefits and joys that accompany a teacher's journey, there are also incredible challenges in medical schools of Nepal. Doubts have been raised about the validity, reliability, practicality and qualifications of teachers in terms of competencies and quality education in medical sciences. Doctors as teachers and teachers as non-doctors have been the charm of basic medical science from the beginning of medical education. History speaks not only in
Nepal, but in the entire world most of the teaching faculties in basic medical science are from MSc and PhD background. Those teachers who made doctors by devoting and spending their glorious age, valuable time, and more than a decade in service at teaching to Nepalese medical schools especially in basic science with non MD qualification are at the doors of judiciary for the injustice made to teachers by medical council.

Academic qualification is the basis, but not the base. Base of good teachers are developed from hard work and passion towards the teaching profession. Teachers are wandering for justice stigma and social security nowadays. Academic careers are not only for students, but also for the teachers as teaching and learning is a regular continuous process. The decision of medical council towards diminishing the number of teaching faculties may be fruitful towards the cost minimization of medical school but will not lead to excellence medical education. Medical schools in Nepal are finding it easy to forget teachers for their long term dedication, contribution, sacrifice and service of teaching in medical science.

At this juncture, universities, policy makers and the governing regulating bodies should re-think, amend and immediately kick out this social injustice, degree based disparity and should create uniformity in rules and regulations to build a healthy competitive environment among teachers at medical schools of Nepal to enhance the quality medical education. Good teachers are able to weave a complex web of connections between themselves, their subjects, and their students, so that students can learn to weave a world for themselves. The connections made by good teachers are held not in their methods 
but in their hearts where intellect, emotion and spirit will converge in the human self [20]. Teaching is the profession of honesty and teachers should be regarded everywhere. The greatest satisfactions of teachers are found not in pay or promotion but in psychic rewards of respect and prestige from the surroundings.

Not only in medical schools, throughout the world, teachers are found in every sector of academics. Teachers are often considered the backbone of schools; without them there would be no school. Thus, understanding teacher's role is key to understanding the educational system. But, due to lack of independence, ineffective organizational support, guiding principles and biased decisions, defective monitoring and assessment system, insufficient resources, low payment, lack of promotion, social stigma, rapid privatization, lack of working environment, less job opportunity, restricted prospect of career development and ineffective negotiations are the hindering factors in the development of teachers. Teachers are the backbone of nation. Moreover, teachers need to achieve autonomy in controlling and maintaining the integrity of its professional education and governing regulatory bodies. Because, I believe "Teacher with a pen is more powerful than the warrior with a sword. A teacher is not just a teacher."

\section{REFERENCES}

1. V. Ravi. Teacher Education. e-book. Page no.58

2. Jan H. Teacher of 21st Century: Characteristics and Development Research on Humanities and Social Sciences 2017; 7(9):50-54

3. Shankar PR. The best teacher is the one who does not 'teach'! Janaki Medical College Journal of Medical Sciences 2016; 4(1): 1-4

4. Shankar PR, Dubey AK, Subish P, Upadhyay DK. Medical student attitudes towards and perception of the basic sciences in a medical college in western Nepal. J Int Association Med Sci Educators 2007;1 7(1):67-73

5. Ronald JM. What makes a good teacher? Lessons from teaching medical schools. Acad med 2001; 76: 809.

6. British Medical Association. Role models in academic medicine. London: BMA. 2005.

7. Lamichhane J. Dilemma of medical graduates in Nepal. J Nepal Health Res Council 2010;8:116-9

8. Ansari M. Quality of Medical Education in Nepal Education for Health 2012; 25 (2) :130

9. Hasan T, Bani I, Ageel H, Fauzi M. An Ideal Medical Teacher, Education in Medicine Journal 2011; Vol.3 (1): e54-e59

10. Harden R. AMEE Guide 21: curriculum mapping: a tool for transparent and authentic teaching and learning. Evaluating the outcomes of undergraduate medical education. Medical Education. 2003.

11. Wright SM, Kern DE, Kolodner K, Howard DM, Brancati FL. Attributes of excellent attendingphysician role models. N Engl J Med 1998;339:198693.

12. Harden RM, Crosby J. AMEE guide no. 20: The good teacher is more than a lecturer-the twelve roles of the teacher. Medical Teacher 2000; 22: 334-347.

13. Karki DB, Dixit H. An overview of undergraduate and postgraduate medical education in Nepal and elsewhere. Kathmandu University medical journal (KUMJ). 2004;2(1):69-74

14. Pokhrel R. Medical Education in Nepal and Brain Drain MJSBH 2017; 16(1):1-2

15. Parsell G, Bligh J. Recent perspectives on clinical teaching. Med Edu 2001; 35: 409-14.

16. Macdonald J. A survey of staff attitudes to increasing medical undergraduate education in a district general hospital. Med Edu 2005; 39: 688-95.

17. Hendry RG, Kawai GK, Moody WE et al. Consultant attitudes to undertaking undergraduate teaching duties: perspectives from hospitals serving a large medical school. Med Edu 2005 39: 1129-39.

18. Finucane P, Allery LA, Hayes TM. Attitudes to teaching among teachers at a British medical school. Med Edu 1994; 28: 213-9.

19. Accreditation Standards for the MBBS (Bachelor of Medicine and Bachelor of Surgery) Program 2017. Nepal Medical Council Bansbari, Kathmandu, Nepal

20. "Good Talk about Good Teaching: Improving Teaching Through Conversation and Community." Change, Nov./Dec., 1993. A revised version of this article appears as Chapter VI in The Courage to Teach.

Correspondence to:
Satyam Prakash
Assistant Professor
Department of Biochemistry
Janaki Medical College Teaching Hospital
Tribhuvan University, Nepal
E-mail: sprakashy2424@gmail.com

